\title{
Histomorphometric Study of the Glomeruli of the Kidney in Bangladeshi Population
}

\author{
Fatema Johora ${ }^{1}$,Abu Sadat Mohammad Nurunnabi ${ }^{2}$, Sunjida Shahriah ${ }^{3}$, Rukshana Ahmed ${ }^{4}$, \\ Shamim Ara ${ }^{5}$
}

\begin{abstract}
Background: Controversies still prevail on glomerular changes of kidney whether due to normal aging or its association with diseases. Objective: The aim of the present study was to see the variation in number and size of the glomeruli of kidney with increasing age in a Bangladeshi population based on autopsy. Methods: This cross-sectional, descriptive study was done in the Department of Anatomy, Dhaka Medical College, Dhaka, from July 2008 to June 2009, based on collection of 140 post mortem human kidneys collected from 70 unclaimed dead bodies from the morgue. All the samples were divided into three age-groups: 10-19 years, 20-39 years and 40-59 years. Histological slides were prepared by using routine Harris' Haematoxylin and Eosin (H \& E) stain. The number of glomeruli was measured by point counting technique, while the size (diameter) was measured by using ocular and stage micrometer. Results: The mean $\pm \mathrm{SE}$ number of glomeruli per sq. $\mathrm{mm}$ found in the right and left kidney were $8.45 \pm 0.52$ and $8.67 \pm 0.80$ in group $10-19$ years, $9.90 \pm 0.42$ and $9.92 \pm 0.47$ in 20-39 years, and $8.52 \pm 0.18$ and $8.55 \pm 0.16$ in $40-59$ years respectively. Besides, the size (mean \pm SE diameter) of glomeruli was found in the right and left kidney were $43.96 \pm 3.01 \mathrm{ìm}$ and $143.92 \pm 2.90 \mathrm{im}$ in group 10-19 years, $153.69 \pm 5.18 \mathrm{im}$ and $153.61 \pm 5.24 \mathrm{im}$ in $20-39$ years, and $140.48 \pm 0.95 \mathrm{ìm}$ and $140.78 \pm 0.88 \mathrm{ìm}$ in 40-59 years respectively. Conclusion: No difference was found in number and size of glomeruli between right and left kidney in any group. Similarly, no difference was also evident among different age groups.
\end{abstract}

Key words: Histomorphometry, glomerulus, kidney function, human kidney.

Bangladesh Soc Physiol. 2014, June; 9(1): 11-16 For Authors Affiliation, see end of text.

http://www.banglajol.info/index.php/JBSP

\section{Introduction}

${ }^{6} \mathrm{~W}$ hat is a human but an ingenious machine designed to turn, with infinite artfulness, the red wine of Shiraz into urine?" - so said the story teller in Isak Dinesen's 'Seven Gothic

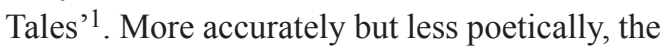
human kidneys serve to convert more than 1700 litres of blood per day into about 1 litre of highly

Received Jan. 2014;

Accepted April 2014

J Bangladesh Soc Physiol. 2014, June; 9(1): 11-16 specialized concentrated fluid called 'urine'. By doing so kidney excretes the metabolic waste products, precisely regulates the body's concentration of water and salt and maintains the appropriate acid-base balance of plasma ${ }^{2}$. This functional richness is reflected in its structural complexity especially in the filtrating $\operatorname{part}^{2,3}$. Renal corpuscle, the filtration component of kidney, consists of glomerulus and Bowman's capsule $^{3,4}$. Glomerulus is a tuft of capillaries 
composed of 10-20 capillary loops, where blood flows through to undergo a filtration process to produce the initial urine filtrate ${ }^{4}$. Several studies suggested age related changes in the number and size of glomeruli in normal people ${ }^{5-7}$. Glomerulopathies are the most common cause of end-stage renal disease ${ }^{8,9}$. Not only do different diseases primarily affecting the glomerulus have clinical features in common but, because of the limited number of ways in which tissue can respond to injury, there may be similarities in structural changes as well. Hence, disease process of the kidney somehow associated with varying degree of changes in glomeruli ranging from proliferation and exudation to thickening of basement membrane and necrosis or sclerosis. ${ }^{8}$ Several studies suggested that changes in the number and size of glomeruli have been linked to some renal and systemic diseases ${ }^{9,10}$. However, discrepant findings exist among studies of changes in the average glomerular size with aging. Some have reported the glomerular surface area or volume to decline with age, ${ }^{5,11}$ whereas others have found no change ${ }^{12}$ or an increase with age ${ }^{6,13,14}$. Besides its size, glomerular density (number of glomeruli per area of cortex) is an inversely proportional surrogate for the average nephron size ${ }^{15}$. Glomerular density inversely correlates with glomerular size and is a potent predictor of GFR decline in early IgA and membranous nephropathy ${ }^{16,17}$. Thus, controversies still prevail on glomerular changes of kidney whether due to normal aging or its association with diseases. Therefore, we proposed this microscopic study to see the variation in number and size of the glomeruli of kidney with increasing age in a Bangladeshi population (who were not suffering from known kidney disease). The results of the present study are expected to enrich the information pool for researchers and clinicians and can be used as a standard reference for the kidney of Bangladeshi people.

\section{Methods}

This cross-sectional, descriptive study was done in the Department of Anatomy, Dhaka Medical College, Dhaka, from July 2008 to June 2009, based on collection of 140 post mortem human kidneys collected from 70 unclaimed dead bodies which were in the morgue under examination in the Department of Forensic Medicine, Dhaka Medical College, Dhaka. All the samples were taken from medicolegal cases excluding poisoning, any cutting or crushing injury to the kidneys, kidney found in one side or grossly abnormal in shape/ size and from patients suffering from any kidney disease. The present study was approved by the Ethical Review Committee of Dhaka Medical College, Dhaka.

Grouping of the samples: For convenient description of various changes of the glomeruli of the kidney in relation to age, the collected samples were divided into three age groups including 10-19 years, 20-39 years and 40-59 years, according to Darmady et al. ${ }^{5}$.

Procedure of histological study: Tissue blocks were fixed in $10 \%$ formol saline in a plastic container. The tissues were washed in running tap water, dehydration was done with ascending grades of alcohol, cleared with xylene, infiltrated and embedded in paraffin. Paraffin blocks were cut at $5 \mathrm{~mm}$ thickness and were stained with routine Harris' Haematoxylin and Eosin (H \& E) stain. Five best prepared slides from group A, ten from group $\mathrm{B}$ and five from group $\mathrm{C}$ were examined under light compound microscope (Olympus CHB, Made in Japan).

Counting of number of glomeruli: For counting the number of glomeruli the slides were viewed under low magnification $(\times 10$ objectives, $\times 10$ eyepiece). The number of glomeruli per unit area of microscopic field for each slide was calculated by point counting technique and their mean is recorded, according to Nurunnabi et al. ${ }^{18}$.

Measurement of size (average diameter) of glomeruli: For measurement of diameter of

J Bangladesh Soc Physiol. 2014, June; 9(1): 11-16 
glomeruli, the slides were also examined under low magnification $(\times 10$ objectives, $\times 10$ eyepiece $)$, by using a stage micrometer and ocular micrometer. Two measurements were taken for each glomerulus. One measurement was taken at the maximum transverse diameter of the glomerulus (Figure 1) and the other was perpendicular to the previous one. Hence, the transvertical diameter of the glomerulus was measured by taking the mean of the two diameters as follows:

Average diameter $=($ Maximum transverse diameter + Maximum perpendicular diameter $) \div 2$

The stage micrometer calibration was focused under 10 objective and the ocular micrometer calibration was super imposed on them in such a way that the starting mark on the ocular micrometer matches exactly with the starting mark on the stage micrometer. Then the marker on the stage and ocular micrometer that corresponds to each other most closely was noted. In this way, determination of how many of the smallest division of the ocular micrometer corresponded with how many of the smallest division of the stage micrometer was done. Then the calculation was done to determine the average diameter of each glomerulus of kidney and converted into a ìm value, according to Nurunnabi et al. ${ }^{18}$.

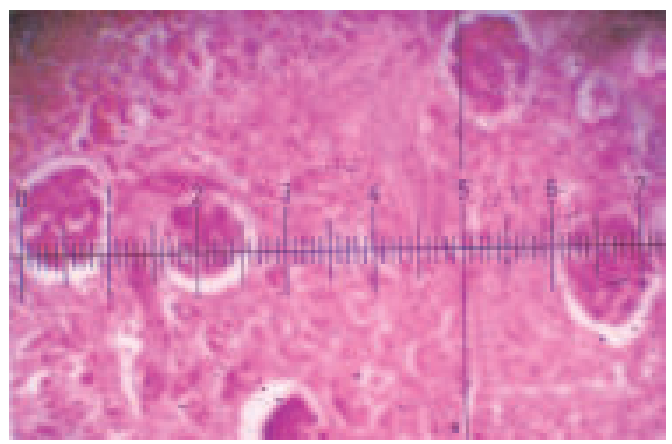

Figure 1 : Photomicrograph of the human kidney, taken from age group20-39 years, showing the measuring procedure of size (diameter) of a glomerulus by using ocular micrometer, $(\times 100$ magnification) (H \& E stain).

Statistical processing of data: The data collected were processed and statistical analyses were done by using SPSS version 13.0. Data was expressed as mean and SD. The comparison between the right and the left was done by using unpaired Student's ' $t$ ' test and in between different groups by One-way ANOVA test.

\section{Results}

In the present study, the mean $\pm \mathrm{SD}$ number of glomeruli per sq. $\mathrm{mm}$ found in the right and left kidney were $8.45 \pm 0.52$ and $8.67 \pm 0.80$ in 10 - 19 years, $9.90 \pm 0.42$ and $9.92 \pm 0.47$ in 20 - 39 years, and $8.52 \pm 0.18$ and $8.55 \pm 0.16$ in age group $40-49$ years respectively (Table I). Besides, the size (diameter) of glomeruli was found in the right and left kidney were $43.96 \pm 3.01 \mathrm{im}$ and $143.92 \pm 2.90 \mathrm{im}$ in 10-19 years, $153.69 \pm 5.18 \mathrm{ìm}$ and $153.61 \pm 5.24 \mathrm{ìm}$ in 20-39 years and $140.48 \pm 0.95 \mathrm{ìm}$ and $140.78 \pm 0.88 \mathrm{im}$ in 40 49 years respectively (Table II). No difference was found in number and size of glomeruli between right and left kidney in any group $(P>0.50)$. Similarly, no difference was evident among different age groups.

Table I: Mean \pm SD number of glomeruli per sq. $\mathrm{mm}$ in right and left kidney in different age $\operatorname{group}(\mathrm{n}=20)$

\begin{tabular}{lcc}
\hline Age $(\mathrm{yr})$ & Right Kidney & Left Kidney \\
\hline $10-19(\mathrm{n}=5)$ & $8.45 \pm 0.52$ & $8.67 \pm 0.80$ \\
& $(7.90-8.96)$ & $(7.96-9.90)$ \\
& $9.90 \pm 0.42$ & $9.92 \pm 0.47$ \\
$20-39(\mathrm{n}=10)$ & $(9.20-10.40)$ & $(9.29-10.70)$ \\
& $8.52 \pm 0.18$ & $8.55 \pm 0.16$ \\
$40-59(\mathrm{n}=5)$ & $(8.20-8.80)$ & $(8.35-8.70)$ \\
\hline
\end{tabular}

Table II: Mean \pm SD diameter(ìm ) of glomeruli in right and left kidney in different age group $(n=20)$

\begin{tabular}{ccc}
\hline Age group & Right Kidney & Left Kidney \\
\hline $10-19(n=5)$ & $143.96 \pm 3.01$ & $143.92 \pm 2.90$ \\
& $(140.20-148.30)$ & $(140.30-148.20)$ \\
$20-39(n=10)$ & $153.69 \pm 5.18$ & $153.61 \pm 5.24$ \\
& $(142.80-160.50)$ & $(142.60-160.30)$ \\
$40-59(n=5)$ & $140.48 \pm 0.95$ & $140.78 \pm 0.88$ \\
& $(140.20-142.50)$ & $(140.20-142.30)$ \\
\hline
\end{tabular}

Figures in the parentheses indicate range. 


\section{Discussion}

The association of lower glomerular number with hypertension and renal insufficiency was described in the 1930s. Hence, low glomerular number has become an important determinant of hypertension and renal disease ${ }^{8}$. Moore ${ }^{19}$ concluded that the normal human kidney from birth to the age of 40 years contained $0.8 \times 10^{6}$ glomeruli with a range of $(0.60$ to 1.2$) \times 10^{6}$. After 40 , there was a steady loss of nephrons. Tauchi et al. ${ }^{20}$ examined the kidneys of Japanese and Caucasians and reported a decrease in the number of parenchymal cells and tendency to increase in the size of cells as the main characteristics of senile changes. The size of glomeruli did not show any marked change with age in Caucasians, whereas in Japanese, there a significant decrease was evident in their size. Dunnill \& Halley ${ }^{21}$ stated that the total number of glomeruli in both kidneys were 210,106 . The number remained at approximately same in all cases until 36 years, then the number declines. Mclachlan ${ }^{22}$ reported that between fourth and seventh decades, glomerular number becomes a half. Anderson \& Brenner ${ }^{23}$ suggested that the number of functioning glomeruli declines roughly with the changes in the renal weight with age. Hoy et al. ${ }^{12}$ performed a multiracial study on 78 kidneys and found the glomerular number ranged from 210,332 to $1,825,380$; however, it decreased throughout adult life. He concluded that people with low glomerular number are predisposed to renal insufficiency. Darmady et al. ${ }^{5}$ studied 105 human kidneys from term to 101 years and observed that after the third decade sclerosing glomeruli were present in all ages and at the same time there was reduction in the size of glomeruli and number of nephron with age. Goyal ${ }^{6}$ studied with 100 human postmortem kidneys from 1 to 70 years of age and found the number of the glomerular tuft per unit area decreased significantly with advancing age. Alam ${ }^{24}$ studied on 15 kidneys and observed that glomerular number per sq. $\mathrm{mm}$ was $2.57 \pm 0.12,2.38 \pm 0.14$ and $1.83 \pm 0.10$ in age group 5-15 years, $16-35$ years and $36-60$ years respectively. He also found the size (diameter) of glomerulus was $0.23 \pm 0.002 \mathrm{ìm}, 0.23 \pm 0.001 \mathrm{ìm}$ and $0.20 \pm 0.002 \mathrm{im}$ in this 3 age groups respectively. Banik $^{25}$ examined and found the glomerular number of right and left kidneys $4.85 \pm 0.39$ and $4.85 \pm 0.61 ; 4.41 \pm 0.42$ and $4.41 \pm 0.54 ; 3.26 \pm 0.39$ and $3.44 \pm 0.44$ in group $\mathrm{A}(6-20$ years), $\mathrm{B}$ (21-36 years) and $\mathrm{C}$ (37-65 years) respectively. Nahar ${ }^{26}$ examined 18 pairs of kidneys and found the glomerular number of right and left kidneys $5.03 \pm 0.35$ and $5.03 \pm 0.47 ; 4.93 \pm 0.15$ and $4.97 \pm 0.23$;

$3.11 \pm 0.47$ and $3.09 \pm 0.45$ in $12-20$ years, $21-40$ years and $41-65$ years respectively. Zaman et al. ${ }^{27}$ studied 60 cadaveric specimens and reported that the mean $\pm \mathrm{SE}$ diameter of glomeruli of the right and left kidney were $101.81 \pm 2.72 \mathrm{im}$ and $101.51 \pm 2.53 \mathrm{ìm} ; 132.66 \pm 2.37 \mathrm{ìm}$ and $132.79 \pm 1.99 \mathrm{im}$; $127.94 \pm 3.12 \mathrm{im}$ and $128.08 \pm 3.33 \mathrm{im}$ in 3 age groups 3-20 years), 21-40 years and 41-60 years respectively. An MRI-based study, done by Beeman et al. ${ }^{28}$, showed that counts yielded $33,786 \pm 3,753$ labeled glomeruli ( $\mathrm{n}=5$ kidneys) and acid maceration counting of contralateral kidneys yielded an estimate of $30,585 \pm 2,053$ glomeruli $(\mathrm{n}=6$ kidneys). Besides, disector/fractionator stereology counting yielded an estimate of 34,963 glomeruli $(\mathrm{n}=2)$. The differences among those research results may be attributable to differences in racial distribution and measurement techniques.

\section{Conclusion}

Our study revealed that there is no difference in number and size of glomeruli between right and left kidney. Besides, no statistically significant difference is evident in number and size of glomeruli among different age groups in Bangladeshi population in the present study. Hence, according to our findings, we are in favour of the proposition that changes in the number and size of glomeruli may be linked to renal and systemic diseases; and less likely with advancing age. 


\section{Authors affiliation}

1. Fatema Johora, Assistant Professor, Department of Anatomy, OSD, Directorate General of Health Services (DGHS), Dhaka.

2. Abu Sadat Mohammad Nurunnabi, Assistant Professor, Department of Anatomy, OSD, Directorate General of Health Services (DGHS), Dhaka. Cell Phone: +8801712290608, Email: shekhor19@yahoo.com

3. Sunjida Shahriah, Associate Professor, Department of Anatomy, Z.H. Sikder Women's Medical College, Dhaka.

4. Rukshana Ahmed, Associate Professor, Department of Anatomy, OSD, Directorate General of Health Services (DGHS), Dhaka.

5. Shamim Ara, Professor \& Head, Department of Anatomy, Dhaka Medical College, Dhaka.

* For correspondence

\section{Acknowledgement}

We would like to express our gratitude to the authority of Health, Nutrition \& Population Sector Programme (HNPSP) of Directorate General of Health Services (DGHS) of the Government of the People's Republic of Bangladesh, and Principal, Dhaka Medical College, Dhaka, for providing us with the research grant to support this study.

\section{References}

1. Alpers CE. The kidney. In: Kumar V, Abbas AK, Fausto N. Aster JC. eds. Robbins and Cotran pathologic basis of disease. $8^{\text {th }}$ ed. New Delhi: Saunders Elsevier; 2010: p.905-69.

2. Keele CA, Neil E, Joels N. eds. The kidney and the regulation of body fluids. In: Samson Wright's applied physiology. $13^{\text {th }}$ ed. New Delhi: Oxford University Press; 2000: p.218-37.

3. Healy JC. Kidney and ureter. In: Standring S, Borley NR, Collins P, Crossman AR, Gatzoulis MA, Healy $\mathrm{JC}$, et al. eds. Gray's anatomy: the anatomical basis of clinical practice. $40^{\text {th }}$ ed. Edinburgh: Elsevier Churchill Livingstone; 2008: p.1225-38.

4. Ross MH, Pawlina W. Histology: a text and atlas with correlated cell and molecular biology. $6^{\text {th }}$ ed. Baltimore: Lippincott Williams \& Wilkins; 2011: p.698-714.

5. Darmady EM, Offer J, Woodhouse MA. The parameters of the ageing kidney. J Pathol 1973; 109(3): 195-207.

J Bangladesh Soc Physiol. 2014, June; 9(1): 11-16
6. Goyal VK. Change with age in the human kidney. Exp Gerontol 1983; 17(5): 321-31.

7. Mañalich R, Reyes L, Herrera M, Melendi C, Fundora I. Relationship between weight at birth and the number and size of renal glomeruli in humans: a histomorphometric study. Kidney Int 2000; 58(2): 770-3.

8. Papper S. The glomerulopathies. In: Clinical nephrology. $2^{\text {nd }}$ ed. Boston: Little, Brown \& Co; 1978: p.171-215.

9. Brenner BM, Garcia DL, Anderson S. Glomeruli and blood pressure. Less of one, more the other? Am J Hypertens 1988; 1(4 Pt.1): 335-47.

10. Hoy WE, Bertram JF, Denton RD, Zimanyi M, Samuel T, Hughson MD. Nephron number, glomerular volume, renal disease and hypertension. Curr Opin Nephrol Hypertens 2008; 17(3): 258-65.

11. Nyengaard JR, Bendtsen TF. Glomerular number and size in relation to age, kidney weight, and body surface in normal man. Anat Rec 1992; 232(2): 194-201.

12. Hoy WE, Douglas-Denton RN, Hughson MD, Cass A, Johnson K, Bertram JF. A stereological study of glomerular number and volume: preliminary findings in a multiracial study of kidneys at autopsy. Kidney Int Suppl 2003; 83: 31-7.

13. Abdi R, Slakey D, Kittur D. Heterogeneity of glomerular size in normal donor kidneys: impact of race. Am J Kidney Dis 1998; 32: 43-6.

14. Fulladosa X, Moreso F, Narváez JA, Grinyó JM, Serón D. Estimation of total glomerular number in stable renal transplants. J Am Soc Nephrol 2003; 14(10): 2662-8

15. Rule AD, Semret MH, Amer H, Cornell LD, Taler SJ, Lieske JC, et al. Association of kidney function and metabolic risk factors with density of glomeruli on renal biopsy samples from living donors. Mayo Clinic Proc 2011; 86(4): 282-90.

16. Tsuboi N, Kawamura T, Koike K, Okonogi H, Hirano K, Hamaguchi A, et al. Glomerular density in renal biopsy specimens predicts the long-term prognosis of IgA nephropathy. Clin J Am Soc Nephrol 2010; 5(1): 39-44.

17. Tsuboi N, Kawamura T, Yoichi M, Utsunomiya Y, Hosoya T. Low glomerular density is a risk factor for progression in idiopathic membranous 
nephropathy. Nephrol Dial Transplant 2011; 26(11): 3555-60.

18. Nurunnabi ASM, Mahbub S, Shahriah S, Begum GN, Ara S. Thyroid follicles and parenchyma are found to increase with advancing age during the first 50 years of life in Bangladeshi people. J Bangladesh Soc Physiol 2009; 4(2): 88-92.

19. Moore RA. The total number of glomeruli in the normal human kidney. Anat Rec 1931; 48(1): 153-68.

20. Tauchi H, Tsuboi K, Okutomi J. Age changes in the human kidney of the different races. Gerontologia 1971; 17(2): 87-97.

21. Dunnill MS, Halley W. Some observations on the quantitative anatomy of the kidney. J Pathol 1973; 110: 113-21.

22. Mclachlan MSF. The ageing kidney. Lancet 1978; 312(8081): 143-6.

23. Anderson S, Brenner BM. Effect of aging on renal glomerulus. Am J Med 1986; 80(3): 435-42.
24. Alam MZ. Gross morphological and histological features of kidneys in Bangladeshi people [thesis]. Dhaka: IPGMR, University of Dhaka; 1994.

25. Banik S. Gross and histomorphological study of human postmortem kidney in Bangladeshi people [thesis]. Dhaka: Sir Salimullah Medical College, University of Dhaka; 2005.

26. Nahar A. Histomorphological study of human kidney in Bangladeshi people [thesis]. Dhaka: Dhaka Medical College, University of Dhaka; 2006.

27. Zaman UKS, Khalil M, Rahman MM, Ara ZG, Afrin S, Sultana ZR. Histological changes of human kidney with age in Bangladeshi people. Bangladesh Med J 2011; 40(1): 13-7.

28. Beeman SC, Zhang M, Gubhaju L, Wu T, Bertram $\mathrm{JF}$, Frakes DH, et al. Measuring glomerular number and size in perfused kidneys using MRI. Am J Physiol 2011; 300(6): 1454-7. 